\title{
Risk for Falls in Patients with Limb Amputations in the Clinical Institute for Rehabilitation and Orthopedic Aids of the University Hospital Centre Zagreb
}

1 Danijela Golub

2 Slađana Režić

1 Clinical Institute for Rehabilitation and Orthopedic Aids, UHC Zagreb, Croatia

2 Department for Health Care Quality Assurance and Improvement, UHC Zagreb, Croatia

Article received: 08.03.2021.

Article accepted: 29.04.2021.

Author for correspondence:

Slađana Režić

Department for Health Care Quality Assurance and Improvement, UHC Zagreb

Kišpatićeva 12, Zagreb, Croatia

E-mail: sladjana.rezic@gmail.com

https://doi.org/10.24141/2/5/1/6

Keywords: fall, risk of falls, Morse Falls Scale, limb amputation

\section{Abstract}

Introduction. Patient falls are a significant clinical problem, as the fall can result in disability and, in some cases, death. The fall affects the patients' quality of life, prolongs hospitalization, and increases the cost of treatment. Falls are the result of interaction between various factors. In the hospital setting, falls are considered adverse events.

Aim. To determine the number of patients' falls at the Clinical Institute for Rehabilitation and Orthopedic Aids of the University Hospital Centre Zagreb (UHC Zagreb) between September 1, 2019, and February 29, 2020.

Methods. The data was extracted after the event from the Hospital Information System (Nursing records) and then processed. The study included 212 patients with limb amputations (both sexes) who were hospitalized in the Clinical Institute for Rehabilitation and Orthopedic Aids.

Results. The results showed that patients with limb amputations have a risk for falls when doing rehabilitation for their primary diagnosis. Of the 212 patients admitted, 209 were at risk of falling according to the Morse Falls Scale, but of the total number of patients, only 2 fell.

Conclusion. Patients with limb amputations have a higher risk of falls. The retrospective study shows that despite the increased risk of falls, the actual number of falls is very small. This shows that the medical staff are doing excellent work. 


\section{Introduction}

The World Health Organization defines a fall as an event which results in a person coming to rest inadvertently on the ground or floor with the inability to get up, and which occurs under circumstances affected by many factors that affect stability (1). In hospital settings, falls represent a significant clinical problem because they often result in injuries, thereby extending the duration of hospitalization and increasing the cost of treatment. More than $70 \%$ of falls occurred in rooms, when moving into a bed, chair, or wheelchair, and $19 \%$ when moving patients from a bed to the bathroom and vice versa (1).

In patients with amputations, the energy expenditure required for walking, both without and with a prosthesis, plays a major role. The reason for this is the increased metabolic oxygen consumption, which is up to 70 times higher in people with above-theknee amputations, and 40 times higher than normal in below-the-knee amputations. Although the data could suggest that the risk of fall is greater in patients with above-the-knee amputations, in everyday work we more often see falls occurring in patients with below-the-knee amputations. This is especially true in younger patients who overestimate their sense of balance and their capabilities (2). A study conducted in the UK showed that the incidence rate of falls among amputated patients was $32 \%$, while another study in Canada showed an incidence rate of $20.5 \%$ (3). Vu et al. cite diabetes and below-the-knee amputations as decisive factors in the risk of fall (4).

\section{Fall prevention in patients with lower limb amputation}

The Clinical Institute for Rehabilitation and Orthopedic Aids conducts primary and secondary prosthesis provision and rehabilitation, providing patients with walking aids such as prostheses, crutches, or walkers. When prosthesis provision is not possible, patients are provided with a wheelchair.

After amputation, patients encounter many difficulties in everyday life, such as mental and physical adaptation to the new situation, overcoming numerous obstacles, returning to daily activities, adjusting environmental conditions (reducing obstacles such as thresholds, carpets, electrical installations, adjust- ing the bathroom). After amputation, patients have a disturbed sense of balance, and so when they get up, they often forget that they do not have a leg, and thus a fall happens, possibly causing an injury. Because of pain in the remaining part of the leg, but also because of phantom pain, patients use pain medication that can also disturb their sense of balance.

Incorrect use of walking aids (crutches, walker, wheelchair) is also a contributing factor, increasing the risk of falls in patients with amputations. Interventions in amputees are primarily focused on day-to-day training in overcoming obstacles, properly using a wheelchair, getting out of bed and walking with crutches or a walker, properly performing bed-to-wheelchair, wheelchair-to-toilet transfers to prevent falls. Interventions must be adjusted to each patient individually, depending on specific personal characteristics.

Adjustment of interventions and the human factor are sometimes not enough to prevent a fall, thus in the Clinical Institute, special attention is given to the adaptation of amputees' rooms, according to the Ordinance on ensuring the accessibility of buildings for people with disabilities and reduced mobility, which justifies its purpose. The installation of transfer aids, the adjustment of bathrooms and toilets, the provision of flat surfaces and the reduction of barriers all lead to better living conditions for patients in the ward, and to a reduction in the risk for falls $(2,5)$.

\section{Consequences of a fall}

Falls in hospital settings are caused by unadapted environments and the patients' altered state of health. Possible consequences mostly affect the patients themselves -their mental and physical health - but they can also affect health workers who were working at the time of the fall. The medical institution also feels the consequences of the fall, because of prolonged hospitalization and increased cost of health care.

Consequently, falls lower the quality of life, making the patients dependent on certain everyday activities that they had hitherto done on their own. Anxiety, depression, fear of repeated falling, loss of selfconfidence, and independence can occur - in short, the patient becomes dependent on other people's help, which affects the whole family.

Injuries in hospital settings that are the result of a fall, can be divided into several categories: 
- no visible injury,

- minor injury - hematoma, scratches,

- moderate injury - fractures, sprains, injuries that require suturing or immobilization,

- serious injury - surgical treatment or transfer to an ICU due to a life-threatening injury is required,

- death (6).

\section{Aims}

1. To determine the number of patient falls, the consequences of a fall, and whether the fall was reported as an adverse event to the Department for Health Care Quality Assurance and Improvement.

2. To determine whether the patient is assessed according to the Morse scale during admission to the Clinical Institute and whether a nursing care plan is written when the assessment shows there is a risk for a fall.

\section{Methods}

A retrospective study on a sample of 212 patients with amputated lower limbs was conducted at the Clinical Institute for Rehabilitation and Orthopedic Aids of the UHC Zagreb between September 1, 2019, and February 29, 2020. The study was approved by the hospital's Ethical Board. The data was retrieved from the Hospital Information System that serves as the operative IT system in the Clinical Institute for Rehabilitation and Orthopedic Aids of the UHC Zagreb.

The study included 212 persons with limb amputations (both sexes) who were hospitalized in the Clinical Institute for Rehabilitation and Orthopedic Aids of the UHC Zagreb during the study period.

Fall risk assessment was conducted using the Morse scale, which uses six variables to easily and quickly calculate the risk of fall (8). The Morse scale parameters include previous falls, other medical diagnoses, mobility aids, presence of an IV-line, posture/movement, and mental status of the patient. The score can be between 0 and 125 points. The result is interpreted in the following way:

- 45 points and over - high risk

- 25 - 44 points - moderate risk

- 0 - 24 points - low risk (7).

The data is shown in a table.

\section{Results}

The study included 122 men and 90 women, which corresponds to the prevalence of amputations both in Croatia and globally, where more males than females have cardiovascular problems. According to a report from the Croatian Health Insurance Fund ( $\mathrm{HZ}$ ZO) from 2019, amputees are 60\% male, and $40 \%$ female (8).

Most respondents belonged to the age group between 61 and 80, i.e., 124 respondents. The average age of respondents was 61,88 . The age range was from 10 to 93 (Table 1 ).

\section{Table 1. Respondent characteristics according to gender and age}

\begin{tabular}{|c|c|c|c|}
\hline \multicolumn{2}{|c|}{$\begin{array}{c}\text { Respondent } \\
\text { characteristics }\end{array}$} & $\mathbf{N}$ & $\%$ \\
\hline \multirow{3}{*}{ Gender } & Male & 122 & 58 \\
\hline & Female & 90 & 42 \\
\hline & Total & 212 & 100 \\
\hline \multirow{5}{*}{ Age } & $1-40$ years & 18 & 8 \\
\hline & $41-60$ years & 50 & 24 \\
\hline & $61-80$ years & 124 & 58 \\
\hline & $\begin{array}{c}81-100 \\
\text { years }\end{array}$ & 20 & 10 \\
\hline & Total & 212 & 100 \\
\hline
\end{tabular}

During the 6-month study period, 48 out of the 212 respondents received primary prosthetic provision and rehabilitation, while 164 received secondary prosthetic provision and rehabilitation. 
Table 2. Respondents with regard to the type of rehabilitation, length of hospitalization and type of amputation

\begin{tabular}{|c|c|c|c|}
\hline \multicolumn{2}{|c|}{ Respondent characteristics } & $\mathbf{N}$ & $\%$ \\
\hline \multirow{3}{*}{ Rehabilitation } & Primary & 48 & 23 \\
\hline & Secondary & 164 & 77 \\
\hline & Total & 212 & 100 \\
\hline \multirow{5}{*}{ Duration of hospitalization } & 1 - 10 days & 45 & 21 \\
\hline & 11 - 20 days & 119 & 56 \\
\hline & 21 - 30 days & 17 & 8 \\
\hline & 31 or more days & 31 & 15 \\
\hline & Total & 212 & 100 \\
\hline \multirow{5}{*}{ Amputation } & Above-the-knee & 88 & 42 \\
\hline & Below-the-knee & 94 & 44 \\
\hline & Bilateral below-the-knee & 24 & 11.5 \\
\hline & $\begin{array}{l}\text { Bilateral above-the-knee/ } \\
\text { below-the-knee and above-the- } \\
\text { knee }\end{array}$ & 5 & 2.5 \\
\hline & Total & 212 & 100 \\
\hline
\end{tabular}

According to hospitalization duration, we distributed the patients into 5 categories: 45 patients were hospitalized up to 10 days, 119 patients were hospitalized between 11 and 20 days, 17 patients were hospitalized between 21 and 30 days, and 31 patients spent more than 31 days in the hospital.

Most patients had a below-the-knee amputation.
On admission, all patients had a Morse scale assessment done. For all patients with a risk for fall according to the Morse scale assessment, a nursing care/ fall risk plan was written, and carried out during the patient's stay on the ward.

The score range on the Morse scale varied between 35 and 75 points, with most patients, 153 of them,

Table 3. Respondents according to the Morse scale assessment and the nursing care plan

\begin{tabular}{|l|c|c|c|}
\hline \multicolumn{2}{|c|}{ Morse scale, nursing care plan } & N & \% \\
\hline \multirow{3}{*}{ Morse scale } & High risk & 209 & 2 \\
\cline { 2 - 4 } & Moderate risk & 3 & 0 \\
\cline { 2 - 4 } & Low risk & 0 & 100 \\
\cline { 2 - 4 } & Total & 212 & 98 \\
\hline \multirow{3}{*}{ Nursing care plan } & Yes & 209 & 2 \\
\cline { 2 - 4 } & No & 3 & 100 \\
\cline { 2 - 4 } & Total & 212 & 2 \\
\hline
\end{tabular}


having a point score of 75. Of all the patients, 3 of them had a moderate fall risk, so for them, a nursing care plan was not written (Table 3).

The number of amputees with recorded falls during hospitalization at the Clinical Institute for Rehabilitation and Orthopedic Aids was 2, i.e., 1\%. Both were reported to the Department for Health Care Quality Assurance and Improvement, with the outcome in the two patients being:

1. The first patient, who was undergoing primary prosthetic rehabilitation for below-the-knee amputation, fell on the balcony of the patient's room, where he stumbled. The patient hit his right shoulder, right leg, and left knee. He had also strained his back. X-rays showed no fractures or strains. After 2 days of rest with cryotherapy and analgesics, the patient continued his rehabilitation.

2. The other patient, a female, also undergoing primary prosthetic rehabilitation for abovethe-knee amputation, slipped from her wheelchair while opening the room door and fell on her right arm. An X-ray revealed anterior dislocation of the shoulder. Repositioning was performed, and a control X-ray revealed a suspicion of a humerus head fracture without displacement. The patient was discharged home in good general condition with status post Luxatio humeri dex, Fractura capiti humeri I. dex. after two days of observation in the ward, with immobilization and recommendations for further treatment.

\section{Discussion}

The study assessed amputee falls at the Clinical Institute for Rehabilitation and Orthopedic Aids of the UHC Zagreb on a sample of 212 respondents. Of these, 122 were male and 90 were female. The larger number of men is in line with data from the World Health Organization and the Croatian Institute for Public Health, which show that the number of men with lower limb amputation, and vascular system diseases is higher than the number of women, in a ratio of $60 \%$ to $40 \%$ (2). Age is an important predic- tor for falls in patients with lower limb amputation, as indicated by the average age of patients, between 61 and 80 years of age. A patient's age affects the expected increase in amputations, doubling the risk for amputation in persons over 65 years of age (5).

Although studies indicate that a fall risk is associated with the level of amputation, given the small number of falls in our study, we cannot conclude whether the fall occurs more frequently in patients with above-the-knee amputation. Namely, in our two fall cases, one was a patient with a below-the-knee amputation, and the second one was a patient with an above-the-knee amputation.

Out of 212 patients, 209 had a high risk of fall according to the Morse scale. For all patients with a risk for fall according to the Morse scale a nursing care plan was written. The plans were carried out during the whole rehabilitation period, i.e., the duration of a patient's hospital stay is equivalent to the duration of the plan implementation.

Steinberg et al. discovered that patients with a lower limb amputation have an increased risk of falls in all rehabilitation phases (9). They state that healthcare professionals must be aware of the risk of falls when caring for people with limb amputations and work daily to reduce the risk factors that lead to falls.

Hunter et al. had similar results. They also found that people with lower limb amputation have an increased risk and that risk factors vary depending on the stages of rehabilitation. They also stated that falls also occur after the discharge of patients, mostly during the first year following the limb amputation (10).

Our data suggests that both patients fell during primary prosthetic rehabilitation, but it is difficult to determine to what extent the rehabilitation phase affected the fall, because of the short patient monitoring period and just two falls during the monitoring period.

\section{Conclusion}

Given the lack of research related to falls, the Clinical Institute for Rehabilitation and Orthopedic Aids of the UHC Zagreb conducted a retrospective study 
on a sample of 212 patients with lower limb amputations. The study showed that a larger number of men were in rehabilitation for limb amputation and that the majority of patients was elderly.

On admission to the ward, all patients were assessed using the Morse scale, and in accordance with the score, a nursing diagnosis stating the risk of fall was written for all patients who had a risk of falling. During the study period, two cases of falls occurred. Both falls were reported to the Department for Health Care Quality Assurance and Improvement.

\section{References}

1. World Health Organization. Global Report on falls Prevention in older Age. Available from: https://www. who.int/ageing/projects/falls_prevention_older_age/ en/

2. Jelić M, Kovač I. Rehabilitacija osoba s amputacijom udova. In: Georgievski- Bobinac, editor. Fizikalna medicina i rehabilitacija u Hrvatskoj. Zagreb. Naklada Frank; 2000. Croatian.

3. Dyer D, Bouman B, Davey M, Ismond KP. An intervention program to reduce falls for adult in-patients following major lower limb amputation. Healthc Q. 2008;11(3 Spec No.):117-21.

4. Vu K, Payne MWC, Hunter SW, Viana R. Risk factors for falls in individuals with lower extremity amputations during the pre-prosthetic phase: a retrospective cohort study. PM R. 2019;11(8):828-833.

5. Seymour R. Prosthetics and Orthotics-lower limb and spinal. Philadelphia: Lippincott Williams \& Wilkins, 2002.

6. Pravilnik o standardima kvalitete zdravstvene zaštite i načinu njihove primjene. Available from: http://narodne-novine.nn.hr/clanci/sluzbeni/2011_07_79_1693. html. Croatian.

7. Pravilnik o sestrinskoj dokumentaciji u bolničkim zdravstvenim ustanovama, NN 79/11, 131/12, 71/16. Available from: https://narodne-novine.nn.hr/clanci/ sluzbeni/2011_07_79_1692.html. Croatian.

8. Kasović M, Fortuna V, Kutle I. Smjernice u prevenciji padova. In:Findak V, urednik. 21. Ljetna škola kineziologa Republike Hrvatske: zbornik radova na temu intenzifikacija vježbanja u područjima edukacije, sporta, sportske rekreacije i kineziterapije 2012 Jun 26-30;Zagreb: Hrvatski kineziološki savez; 2012. p. $425-28$

9. Steinberg N, Gottlieb A, Siev-Ner I, Plotnik M. Fall incidence and associated risk factors among people with a lower limb amputation during various stages of recovery - a systematic review. Disabil Rehabil. 2019;41(15):1778-87.

10. Hunter SW, Batchelor F, Hill KD, Hill AM, Mackintosh $S$, Payne M. Risk Factors for falls in people with a lower limb amputation: a systematic review. PM R. 2017;9(2):170-180.e1. 


\section{RIZIK ZA PAD PACIJENATA S AMPUTACIJOM UDOVA NA KLINIČKOM ZAVODU ZA REHABILITACIJU I ORTOPEDSKA POMAGALA KBC-a ZAGREB}

\section{Sažetak}

Uvod. Pad pacijenta predstavlja znatan klinički problem, jer kao posljedica pada može nastupiti invalidnost, a u nekim slučajevima i smrtni ishod. Pad utječe na kvalitetu života pacijenata, uzrokuje produljenje boravka u bolnici te povećava troškova liječenja. Pad nastaje kao posljedica interakcije brojnih čimbenika. $\mathrm{U}$ bolničkoj zdravstvenoj ustanovi pad spada u neželjene događaje.

Cilj. Utvrditi broj padova pacijenata unutar Kliničkog zavoda za rehabilitaciju i ortopedska pomagala KBC-a Zagreb u periodu od 1. rujna 2019. do 29. veljače 2020.

Metode. Podaci su uzeti retrogradno iz BIS sustava (sestrinska dokumentacija) te su obrađeni. Istraživanje je uključivalo 212 pacijenata s amputacijom udova (oba spola) koji su u navedenom periodu hospitalizirani u Kliničkom zavodu za rehabilitaciju i ortopedska pomagala.

Rezultati. Rezultati su pokazali da pacijenti s amputacijom udova prilikom dolaska na rehabilitaciju zbog svoje primarne dijagnoze imaju rizik za pad. Od 212 zaprimljenih pacijenata 209 ih je imalo rizik za pad prema Morse skali, a od ukupnog broja pacijenata samo su dva pacijenta pala.

Zaključak. Pacijenti s amputacijom udova imaju povećani rizik za pad. Retrospektivno istraživanje pokazuje da je usprkos povećanom riziku za pad broj padova u pacijenata malen. To ukazuje na kvalitetan rad svih zdravstvenih djelatnika.
Ključne riječi: pad, rizik za pad, Morse skala, amputacija udova 